UDC 811.581

\title{
RESULTATIVE SEMATIC CONSTRUCTIONS OF THE MODERN CHINESE LANGUAGE
}

\author{
D. Merzliuk \\ Senior Lecturer of Chinese language, \\ Kyiv National Linguistic University \\ 73, st. Velyka Vasylkivska, Kyiv, 03680, Ukraine \\ denys.merzliuk@knlu.edu.ua \\ O. Yanchuk \\ Student, \\ Kyiv National Linguistic University \\ 73, st. Velyka Vasylkivska, Kyiv, 03680, Ukraine \\ oleksandr.yanchuk@knlu.edu.ua
}

The article deals with resultative semantics that can be conveyed through lexico-grammatical and syntactic means in the Modern Chinese language, as well as the combination of them. Contemporary studies view resultativity within perfective aspect and temporality (category of tense). Thus, it is a functional-semantic category in Modern Chinese. The category represents a situation with an obvious result of the actions that have caused his action. In the Chinese language, the speaker focuses on the consequences of actions that do not reflect internal situational temporality and are only partly comprehended by the speaker. The article refers to the semantic features of resultativeness and resultative constructions functioning. Resultatives introduce postpositional adverbs to a sentence and are constituents of other syntactic complexes as well. Resultativity depicts situations that are dynamic, telic, bound, instantaneous, factitive, and possesses features of evaluation modality and possibility. Each element, but for factitivity and modality, is comprehensible in every communicative situation. Resultative constructions mark the achievement situation type. In addition, these structures belong to completive markers, which denote a resultant moment of the action completion. To be completed, a situation should last a certain limited period of time. Resultatives limit the internal verb temporality; consequently, they define the dynamic features of a situation. Besides, a situation is perceived as integral and inseparable. Hence, a lexical unit denotes the resultant moment of the action. Accordingly, it marks the semantics of instant. Resultatives make the utterance evaluative, since their choice explains the speakers attitude toward the situation. Nonetheless, it is true only for the situations that have already happened; i.e. the facts obtained from the background information. The modality of possibility is conveyed with the help of infixes such as “得” de and “不” bu placed between the parts of resultative constructions to express possibility/impossibility correspondingly.

Keywords: resultativeness, category, resultative constructions, aspect, perfect, Chinese language.

(C) 2021 D. Merzliuk, O. Yanchuk; Published by the A. Yu. Krymskyi Institute of Oriental Studies, NAS of Ukraine and the Ukrainian Association of Sinologists on behalf of The Chinese Studies. This is an Open Access article distributed under the terms of the Creative Commons Attribution License (https://creativecommons.org/licenses/by-nc-nd/4.0/). 


\title{
СЕМАНТИЧНІ ОСОБЛИВОСТІ КАТЕГОРЇ̈ РЕЗУЛЬТАТИВНОСТІ В СУЧАСНІЙ КИТАЙСЬКІЙ МОВІ
}

\author{
Д. О. Мерзлюк, О. О. Янчук
}

У статті розглядається результативна семантика, що в сучасній китайській мові може бути виражена за допомогою як лексико-граматичних, так і синтаксичних засобів, а також шляхом їх поєднання. У сучасних дослідженнях результативність розглядається як складова частина категорії перфекту, тобто вона виступає функційно-семантичною категорією в межах аспектуально-темпорального комплексу сучасної китайської мови. Ця категорія презентує ситуацію як таку, результат якої наявний і $є$ наслідком певних дій, що призвели до нього. Такі дії частково усвідомлюються мовцем, але самі собою не входять до темпоральної структури ситуації, адже мовець фокусує увагу саме на їхньому наслідку. У статті розглянуто семантичні особливості категорії результативності за допомогою аналізу функціонування результативних конструкцій, що найбільш повно відображають результативну семантику, є механізмом введення постпозитивних обставин у речення, а також входять до складу складніших синтаксичних конструкцій. Категорія результативності включає такі семантичні елементи: динамічність, граничність, цілісність, моментальність, фактивність, оцінна модальність та модальність можливості. Усі ці елементи, крім фактивності та модальності, наявні в кожній комунікативній ситуації. Ситуація, що виражається за допомогою результативних конструкцій, належить до класу досягнення. Такі структури є маркером комплетивного аспекту, що вказує на результуючий момент завершення дії. Ситуація повинна тривати протягом певного обмеженого проміжку часу. Елементи результативних конструкцій, надаючи внутрішній темпоральній структурі дієслова ідею межі, обмежують дію, тобто ситуацію із динамічною характеристикою. До того ж ситуація сприймається мовцем як цілісна й неподільна на фази. Отже, лексична одиниця вказує на момент досягнення дією своєї межі. Відповідно до цього формується семантика моментальності. Структурні компоненти результативних конструкцій надають висловлюванню оцінної модальності, оскільки під час їхнього вибору мовець обирає, яке конкретне значення буде найкраще відображати його ставлення до ситуації. Проте це відбувається лише у тих ситуаціях, які вже сталися і $є$ фактами, тобто такими, що підтверджуються іншими джерелами інформації. Модальність можливості виражається за допомогою постановки інфіксів “得” de або “不” $b u$ між компонентами результативних конструкцій для вираження можливості / неможливості ситуації.

Ключові слова: результативність, категорія, результативні конструкції, аспект, перфект, китайська мова.

Постановка проблеми. Стаття присвячена дослідженню семантичних особливостей категорії результативності в сучасній китайській мові. Результативність, або ж комплетивний аспект, належить до кластеру перфективних аспектів та акцентує увагу на результуючій фазі дії. Результат як базове поняття в китайській мові реалізується різноманітними засобами на різних мовних рівнях. Дослідження результативної семантики в сучасній китайській мові дозволяє визначити, яким чином різнорівневі засоби реалізації взаємодіють та формують аспектуальне значення висловлення.

Огляд літератури. Розробкою загальної теорії аспекту займалися Ю.С. Маслов [Маслов 2004], О.В. Бондарко [Теория... 1987], Дж. Байбі та ін. [Bybee et al. 1994], Б. Комрі [Comrie 1976], К. Сміт [Smith 1997]. У працях 
О.В. Бондарка розглядаються питання теорії семантичних категорій [Бондарко 1974], а також теорії значення у функційній граматиці [Бондарко 2002]. Проблемам граматичної семантики різних мов світу присвятив свою працю В.О. Плунгян [Плунгян 2011]. Дослідженням результативного значення в семантиці категорії перфекту займались Б. Комрі [Comrie 1976], Дж. Байбі та ін. [Bybee et al. 1994], К. Сміт [Smith 1997]. Ван Янь у своєму дисертаційному дослідженні розглянула поняття результату та способи його вираження 3 точки зору типології мов Південно-Східної Азії [Wang 2017]. На матеріалі китайської мови дослідженням категорії результативності займались Цзянь Канг Лоap [Loar 2011], Р. Сяо та T. Макенері [Xiao, McEnery 2004]. С.С. Яхонтов виділив у системі граматичних категорій дієслова китайської мови результативний вид та пов'язав результативні дієслова з категорією аспекту [Яхонтов 1957]. Дослідженням функційних та структурних особливостей результативних конструкцій займалась К.В. Антонян [Антонян 2003], а опис їхніх семантичних особливостей поданий у праці Тань Аошуан [Тань 2002]. Ю.С. Любимова визначила місце потенційного способу дієслова в субполі модальності можливості китайської мови [Любимова 2016].

Мета статті - розглянути семантичні особливості категорії результативності в сучасній китайській мові.

Виклад основного матеріалу. Серед аспектологічних досліджень важливе місце посідають дослідження семантики результату. Результативність визначається як складова частина категорії перфекту [Маслов 2004, 426], що може бути визначена як семантична категорія, в основі якої лежить поєднання в одній предикативній одиниці двох часових планів - попереднього та наступного [Теория... 1987, 195].

Б. Комрі виділяє чотири види перфекту, вважає перфект результату найбільш чітким проявом теперішньої релевантності минулих подій [Comrie 1976, 56]. Погоджуючись 3 думкою дослідника, Дж. Байбі та ін. визначають результативне значення як таке, що вказує на стан, до якого призвели певні події у минулому [Bybee et al. 1994, 63].

У слов'янській аспектології прийнято виділяти перфект дії (акціональний) та перфект стану (статальний). Якщо акцент зміщується на пізніший з двох часових планів, поєднаних у предикативній одиниці, то ідеться саме про перфект стану, а набутий стан зумовлюється попередньою дією. Перфект стану також зветься результативом [Маслов 2004, 54, 426-427].

У структурі категорії аспекту вчені виокремлюють такі аспектуальні значення: первинні, що виділяють певний фрагмент ситуації, що потрапив у вікно спостереження мовця, та вторинні, що вказують на перехід дієслова до іншого акціонального класу. Ядром семантичної зони аспектуальності є первинні, або ж лінійні, аспектуальні дієслівні значення [Плунгян 2011, 283-284]. Категорія результативності належить саме до цього типу аспектів, оскільки вона фокусується на зовнішній (результуючій) стадії ситуації [Плунгян 2011, 286].

На думку I.I. Мєщанінова, поняттєвою категорією стає поняття, що отримує у мовній структурі певну побудову, яка знаходить своє вираження в певній лексичній, морфологічній чи синтаксичній системі [Бондарко 1974, 54]. Ознака системи є необхідною умовою визначення семантичної категорії. В іншому випадку йдеться лише про поняття, що існує в етносвідомості [Бондарко 2002, 84]. 
О.В. Бондарко диференціює та доповнює його теорію. У своїй роботі він аналізує семантичні функції елементів поля аспектуальності, які становлять реалізацію певних глибинних поняттєвих категорій. Він також пропонує такі кроки аналізу семантичної категорії: 1) визначення семантичної функції словоформи за контекстом; 2) встановлення можливості заміни цієї форми іншою; 3) визначення особливостей кожної зі словоформ; 4) виділення спільного у їхній семантиці [Бондарко 1974, 54-58].

Таким чином, результативність $є$ семантичною категорією, в основі якої лежить базове поняття результату, тобто наслідку певних здійснених дій. У зв'язку із відсутністю розвиненої морфології в сучасній китайській мові побудова цього поняття проявляється більшою мірою у синтаксичній системі.

Застосовуючи функційні та концептуальні принципи для дослідження синтаксису, Цзянь Канг Лоар визначає, що результативність реалізується у дієслівній постпозиції [Loar 2011, 5]. Дослідниця наводить такі способи вираження семантики результату:

- на лексико-граматичному рівні - результативні конструкції;

- на синтаксичному рівні - речення з прийменниками “把” bă та “被” bèi й речення із опущенням останнього, структури із нейтралізатором предикативності “得” de, а також постпозитивні обставини [Loar 2011, 5-6].

Наявність різнорівневих засобів вираження, правила їхнього функціонування та взаємодії наштовхують нас на думку, що результативність може розглядатися як функційно-семантична категорія, бо, йдучи від сенсу до форми, мовець має свободу у виборі різних одиниць та структур для передачі відтінків сенсу висловлювання.

У цьому дослідженні семантичні особливості категорії результативності будуть розглянуті на матеріалі результативних конструкцій, оскільки ці структури, по-перше, володіють найбільшою кількістю релевантних ознак та, по-друге, функціонують разом з іншими засобами вираження результативності в китайській мові. 3 огляду на це варто звернутися до проблеми визначення засобів реалізації категорії аспектуальності та результативної семантики в працях дослідників.

Б. Комрі вважає, що аспектуальна частка “了” le у китайській мові, вживаючись із предикатами стану, часто вказує, що цей стан є результатом попередніх подій [Comrie 1976, 58]. Цю думку також поділяє С.Є. Яхонтов, вказуючи на те, що ця частка, оформлюючи неграничні дієслова, крім часового значення, надає їм відтінок результативності [Яхонтов 1957, 115]. Однак це твердження виявилось хибним, адже у більш пізніх дослідженнях було визначено, що аспектуальна частка “了” le є показником актуального минулого [Xiao, McEnery $2004,89]$ і не вказує на результат. 3 огляду на це розглянемо результативні конструкції як основний засіб реалізації семантики результату в китайській мові.

Як визначає К.В. Антонян, результативна конструкція (РК) - це двокомпонентна конструкція, перший компонент якої (V1) виражений дієсловом та позначає дію, а другий (V2) виражений дієсловом чи прикметником та позначає дію або стан, що настав в результаті виконання дії, позначеної першим компонентом, або надає їй оцінку [Антонян 2003, 15].

Перший компонент РК є неграничним процесом, що кодується дієсловами класів виконання або діяльності, а другий - зміною стану, що денотується дієсловом стану, а також якісними прикметниками. Окрім цього, місце другого 
компонента можуть займати дієслова класу досягнення. При цьому уся РК розглядається як ситуація класу досягнення [Smith 1997, 283; Loar 2011, 116-117, $123,127]$. Таким чином, результативні конструкції мають усі ознаки класу досягнення.

Першою характеристикою класу досягнення є динамізм, що характерний для усіх процесів, крім статичних. Як вже було зазначено, статальний перфект фокусується на результуючому стані, але не на дії, яка до нього призвела. Отже, процеси, що позначають перші компоненти РК, усвідомлюються мовцем, але не включаються до темпоральної структури РК [Smith 1997, 30]. Це також відображено у структурі РК, де перший компонент - дієслово дії [Xiao, McEnery 2004, 169].

Китайські дослідники визначають РК доволі широко. Вони вважають, що на місці першого компонента РК можуть також стояти дієслова стану, проте в такому разі йдеться не про результат, а про зміну одного стану на інший. Якщо ж місце першого компонента займає прикметник, то вказується на ступінь ознаки [Wang 2017, 54-56]. У нашому розумінні зміна стану є результативною, тільки якщо вона зумовлена дією [Xiao, McEnery 2004, 170], тобто причиною зміни стану є саме динамічна подія, а не стан. Розглянемо такі приклади:

1) 用了整整两个休息日，终于写完了这封并不算长的信。Yòngle zhěngzhěng liăng gè xiūxí rì, zhōngyú xiě wánle zhè fēng bìng bù suàn cháng de xìn. - Після двох повних вихідних я, нарешті, дописав цей, не сказати, що довгий, лист;

2) 我不管你用什么借口, 可是今天一定要办好。Wǒ bùguăn nǐ yòng shénme jièkǒu, kěshì jīntiān yīdìng yào bàn hăo. - Мене не цікавлять твої відмовки, це обов'язково має бути зроблено сьогодні;

3) 比如一张1.3M长的玻璃餐桌, 餐桌面由两块玻璃拼成。Bǐrú ȳi zhāng $1.3 \mathrm{M}$ cháng de bōlí cānzhuō, cānzhuō miàn yóu liăng kuài bōlí pīn chéng. - Наприклад, скляний обідній стіл завдовжки 1,3 метри. Його стільниця складається 3 двох шматків скла.

У наведених прикладах перші компоненти РК належать до дієслів дії, а саме виконання: “写 хіе̌” - «писати» (1), “办 bàn” - «робити, виконувати» (2), “拼 pīn” - «складати, поєднувати» (3). Усі вони описують ситуації, у яких мовець має докласти зусиль до виконання дії для досягнення певної мети, що експлікується за допомогою таких компонентів: “完 wán”- «завершувати» (1), “好 hăo” - «добре» (2), “成 chéng” - «перетворюватись» (3). До того ж,ці РК володіють об’ єктною валентністю.

Наступною ознакою класу досягнення є граничність [Smith 1997, 30]. Другі компоненти РК сигналізують про результат, додаючи поняття кінцевої точки чи мети, тим самим перетворюючи дію на граничну [Loar 2011, 121]. Граничність безпосередньо пов'язана з результатом. О.В. Бондарко стверджує, що результат - це межа, якої досягає спрямований на неї процес, а В.В. Виноградов підтримує думку про те, що результат - це лише частковий випадок межі дії [Теория... 1987, 56]. За Р. Сяо та Т. Макенері, результат зводиться до успішного досягнення кінцевої точки, кодованої дієсловом, коли остання починає мати місце [Xiao, McEnery 2004, 48 ].

Тань Аошуан наполягає на розділенні понять межі, мети та результату. Зазвичай поняття результату та межі тотожні, але іноді дія може обмежуватись 
межею, навіть якщо вона нерезультативна або у певному прояві не має якоїсь мети. Мета - це кінцевий пункт руху [Плунгян 2011, 116], що характерний для дієслів переміщення та результативно спрямованих сполучень. Використання модифікаторів напрямку має виразити межу як досягнення мети дії, але результативність у цих морфемах проявляється лише внаслідок втрати власного значення напрямку [Тань 2002, 240-241]. Незважаючи на розбіжності, можна стверджувати, що семантичною особливістю категорії результативності є граничність. Розглянемо інші приклади:

4) 我回到自己的座位上时, 那女人正在发布一道命令, 命令的内容我没 有听清楚。Wǒ huí dào zìjǐ de zuòwèi shàng shí, nà nürén zhèngzài fābù yīdào mìnglìng, mìnglìng de nèiróng wǒ méiyǒu tīng qīngchǔ. - Коли я повернувся на своє місце, та жінка якраз виголошувала наказ, але я не розчув його змісту;

5) 江泽民强调, 在文件起草过程中要把握好三个问题... Jiāngzémín qiángdiào, zài wénjiàn qǔcăo guòchéng zhōng yào băwò hăo sān gè wèntí...- Цзян Цземінь наголошував, що у процесі підготовки чернетки документа треба вирішити три завдання.;

6) 我试图去做些什么, 改变这一切, 但却什么都没有做到。Wǒ shìtú qù zuò xiē shénme, găibiàn zhè yīqiè, dàn què shénme dōu méiyǒu zuò dào. - Я намагався піти зробити щось, змінити це все, однак нічого не зробив.

У прикладі 4 PK “回到 huí dào” - «повертатись» експліцитно виражає досягнення цілі у вигляді локатива “座位zuòwèi” - «місце», а РК “听清楚 tîng qīngchǔ" - «розчути» імплікує досягнення межі дії “听 tīng” - «чути» шляхом додавання прикметника “清楚 qīngchǔ”, що вказує на ясність отриманих результатів. У прикладі 5 граничність виражається додаванням до дієслова морфеми 好 hăo. Таку ж функцію виконує другий компонент 到 dào у реченні 6.

Серед других компонентів РК є такі, що вказують лише на досягнення межі без внесення додаткових відтінків значення (completive complements). Вони вважаються найбільш граматикалізованими серед інших. Тань Аошуан виділяє 10 таких морфем [Тань 2002, 245], а Р. Сяо та Т. Макенері, проаналізувавши точки зору інших дослідників, виділяють 8 [Xiao, McEnery 2004, 162]. Докладно дослідженням граматикалізації елементів результативних конструкцій займалась К.В. Антонян, яка за допомогою методу кількісної оцінки сполучуваності визначила, що серед других компонентів РК найбільшим ступенем граматикалізації характеризуються 9 морфем [Антонян 2003, 61]. Однак важливо вказати, що про повну граматикалізацію не може ітися, оскільки сполучуваність пов'язана із власним лексичним значенням морфем [Антонян 2003, 70]. У Таблиці 1 наведені другі елементи результативних конструкцій, що визначаються дослідниками як граматикалізовані.

Таким чином, бачимо, що до морфем, які визначаються як найбільш граматикалізовані, належать такі: 完 wán (1), 好 hăo $(2,5,10)$, 着 zháo, 成chéng (3), 到 dào $(6,10)$, 住 zhù $(7)$, а також 见 jiàn.

Результативні конструкції є показниками комплетивного аспекту [Хiao, McEnery 2004, 159], що вказує на момент досягнення межі [Плунгян 2011, 312]. С.Є. Яхонтов визначав РК (хоча й називав їх результативними дієсловами) як такі, що позначають переломний момент у реалізації дії [Яхонтов 1957, 91]. Це підтверджується тим, що ознакою ситуації типу досягнення є моменmaльність. Розглянемо приклади: 
Таблиця 1

Граматикалізація других елементів результативних конструкцій

\begin{tabular}{|l|c|c|c|c|c|c|c|c|}
\hline \multicolumn{1}{|c|}{ Дослідники } & 着 & 到 & 见 & 完 & 过 & 住 & 好 & 成 \\
\hline К.В. Антонян & + & & & + & & + & + & + \\
\hline Тань Аошуан & + & & & + & & + & + & + \\
\hline С.С. Яхонтов & + & & + & & & + & & \\
\hline В.М. Солнцев & & + & & + & & & + & \\
\hline Чжао Юаньжень & + & + & + & + & + & & & \\
\hline К. Сміт & & + & + & + & & & + & + \\
\hline $\begin{array}{l}\text { Р. Сяо та } \\
\text { Т. Макенері }\end{array}$ & + & + & + & + & + & + & + & + \\
\hline
\end{tabular}

7) 地震把柜子震倒, 造就了那条大理石色河川。Dìzhèn bă guìzi zhèn dào, zàojiùle nà tiáo dàlı̌shí sè héchuān. - Землетрус скинув шафу та створив той мармуровий потік;

8) 沈若尘瞅着书里夹的两棵枯萎的小草，骇然呆住了。Chénruòchén chǒuzhe shū lǐ jiā de liăng kē kūwěi de xiăo căo, hàirán dāi zhùle. - Чень Жочень закляк від жаху, дивлячись на дві сухі травинки, стиснуті між сторінками книги;

9) 四年前, 54岁的马丁数次遭窃, 气愤的他用猎枪打死了一名 16 岁男 孩, 打伤了他的同伙。Sì nián qián, 54 suì de mădīng shù cì zāo qiè, qìfèn de tā yòng lièqiāng dă sǐle yī míng 16 suì nánhái, dă shāngle tā de tónghuǒ. - Чотири роки тому, коли п'ятдесятичотирирічного Мартіна уже неодноразово грабували, він, розгнівавшись, убив шістнадцятирічного хлопця із мисливської рушниці та поранив його поплічника.

У наведених прикладах РК описують зміну, що настала внаслідок дії, описаної першим компонентом. Такий перехід від дії до результуючого, як “震 倒 zhèn dào” - «скинути» (7), “呆住 dāi zhù” - «застигнути» (8), “打死 dă sǐ” «вбивати (ударом)» (9), “打伤 dă shāng” - «поранити (ударом)» (9), відбувається одномоментно, адже темпоральна ознака тривалості не є характерною для ситуацій типу досягнення. Однак поняття моментальності є умовним та ідеалізованим [Smith 1997, 19-20], оскільки будь-яка подія триватиме хоча б мізерний відрізок часу.

Р. Сяо та Т. Макенері вказують на те, що РК як маркери комплетивного аспекту характеризуються цілісністю [Хіаo, McEnery 2004, 159]. На думку Тань Аошуан, цілісність - це внутрішня граничність дії, тоді як власне граничність орієнтується на синтаксичний рівень [Тань 2002, 149]. Цілісними $є$ події, що сприймаються як неподільне ціле [Smith 1997, 168]. У таких подіях неможливо виокремити внутрішню фазу дії, оскільки ми споглядаємо дію ніби ззовні. Характеристика цілісності лежить в основі опозиції перфективності - імперфективності [Маслов 2004, 35]. Розглянемо такі приклади:

10) 我们只要把它清洗干净、安装好, 找到煤就行了, 不过, 煤可不容易 找到。Wǒmen zhǐyào bă tā qīngxǐ gānjìng, ānzhuāng hăo, zhăodào méi jiùxíngle, bùguò, méi kěbù róngyì zhăodào. - Нам лише треба його начисто вимити та встановити, знайти вугілля, однак знайти його може бути нелегко;

11) 我们这里水陆码头, 来往人杂, 早已看惯。Wǒmen zhèlǐ shuǐlù mătóu, láiwăng rén zá, zăoyǐ kàn guàn. - У нас тут збирається багато приїжджих на паромному терміналі, ми вже звикли; 
12) 每天喝一点, 喝光它, 将一切忘掉。Měitiān hè yīdiăn, hē guāng tā, jiāng yīqiè wàngdiào. - Кожного дня пийте потроху, коли вип'єте повністю, то все забудете.

PK “清洗干净 qīngxǐ gānjìng” - «вимити (начисто)» (10), “安装好 ānzhuāng hăo" - «встановити» (10), “看惯 kàn guàn” - «звикнути (бачити)» (11), “喝光 hē guāng” - «випити повністю» (12), “忘掉 wàngdiào”- «забути» (12) фокусуються на моменті досягнення дією межі та настанні нового стану, тому дія, яка до нього призвела, сприймається нами як цілісна, без фаз початку, середини чи кінця.

Другі компоненти РК, на думку Тань Аошуан, відіграють важливу роль надання оцінної модальності висловлюванню [Тань 2002, 292-293]. У класифікації других компонентів РК, запропонованій дослідницею, виділяються три такі групи: до групи А належать цілісні дієслова-семельфактиви, які у сполученні із дієсловом вказують на досягнення внутрішньої межі; до групи Б - дієслова, що позначають стан людини та їі справ; до групи В - параметричні та якісні прикметники, що описують стан предмета в результаті дії у практичних сферах діяльності людини [Тань 2002, 245].

Для аналізу других компонентів РК з точки зору висловлення оцінної модальності дослідниця використовує поняття норми, що поділяється на характеристики нормальності та аномальності. Ознаки «норма» та «аномалія» притаманні групам Б і В, причому із переважанням негативних станів. Невідповідність нормі та аномалія не є тотожними. Перша вербалізується за допомогою заперечення та РК із другим елементом позитивної конотації, друга - за допомогою компонента із негативною конотацією. Це пояснюється тим, що норма застосовується тільки до позитивних явищ або до позитивної частини процесу. Важливо також те, що аномальність виражається тільки за допомогою РК [Тань 2002, 297-300]. Розглянемо такі приклади:

13) 玉厚来到公路上, 半天才看清他弟站在路边一棵树影下。Yù hòu lái dào gōnglù shàng, bàntiān cái kàn qīng tā dì zhàn zài lù biān yī kē shù yǐng xià. Юй Хоу вийшов до шосе, довго вдивлявся, аж побачив, що його молодший брат стоїть у тіні дерева біля дороги. У цьому прикладі РК “看清 kàn qīng” «побачити (чітко)» виражає відповідність нормі, оскільки ясність входить до позитивних, бажаних ментальних станів;

14) 你告诉我, 我理解错了题目, 我告诉你, 你理解错了人生。Nǐ gàosù wǒ, wǒ lǐjiě cuòle tímù, wǒ gàosù nǐ, nǔ lǐjiě cuòle rénshēng. - Ти кажеш мені, що я неправильно зрозумів тему, а я тобі кажу, що ти неправильно зрозумів людське життя. На відміну від попереднього прикладу, РК “理解错lǐjiě cuò” - «зрозуміти неправильно» виражає аномальний ментальний стан, бо у своїх фізичних та ментальних діях людина тяжіє до правильності;

15) 电话推销总是不说清楚自己是谁, 来至哪里。Diànhuà tuīxiāo zǒng shì bù shuō qīngchǔ zìjĭ shì shéi, lái zhì nălǐ. - Той, хто телефонує з метою збуту, завжди чітко не називає того, хто він та звідки.

У прикладі 15 наявна саме невідповідність нормі, оскільки вона виражається за допомогою заперечного прислівника “不bù” та РК із другим елементом позитивної конотації “说清楚shuō qīngchǔ” - «сказати чітко, ясно».

Щоб вважатися модальним оператором, РК повинна описувати стан справ, що є фактом, оскільки оцінний модус може реалізовуватись тільки за наявності ознаки фактивності [Тань 2002, 301-302]. 
Оцінний модус тісно пов'язаний із семантикою результату, тому семантика оцінки та факт, що описує РК, утворюють семантичну єдність [Тань 2002, 302]. Розглянемо такі приклади:

16) 等我们回家，我们发现营地空荡荡的，完全被烧光了。Děng wǒmen huí jiā, wǒmen fāxiàn yíngdì kōngdàngdàng de, wánquán bèi shāo guāngle. - Пoвернувшись додому, ми виявили, що військовий табір порожній та повністю згорів;

17) 为了向你爷讨好, 你爸把一点钱全都花光了, 自己还生了重 病。Wèile xiàng nǐ yé tăohăo, nǐ bà bă yīdiăn qián quándōu huā guāngle, zìjǐ hái shēngle zhòngbìng. - Щоб догодити твоєму діду, батько витратив усе до копійки, ще й серйозно захворів;

18) 据女主人说, 电话线在一星期前就拉掉了。Jù nŭ zhǔrén shuō, diànhuà xiàn zài yī xīngqí qián jiù lā diàole. - За словами господині, телефонну лінію відрізали ще тиждень тому.

У цих прикладах події, що описуються, є фактами, які мали місце та не викликають нині сумнівів. Безсумнівність досягається шляхом зіставлення інформації, що отримується 3 різних каналів сприйняття людини, із наявною ситуацією. Через це можна зробити висновок про достовірність описуваних подій. У реченні 16 факт згорання ми можемо побачити очима. Ситуацію витрачання (17) ми відчуваємо відсутністю грошей у гаманці. Про подію відрізання (18) нам відомо зі слів іншої людини, при цьому, можливо, у домі відсутній зв'язок.

Одним із центральних засобів реалізації модальності можливості є потенційний спосіб дієслова [Любимова 2016, 37]. Однією із функційних особливостей результативних конструкцій є утворення потенційних форм шляхом інфіксації морфем “得” de або “不” $b u$ між членами результативної конструкції [Антонян 2003, 52]. Потенційна форма вносить значення можливості / неможливості досягнення результату дією, що кодується РК [Loar 2011, 189]. Вживання потенційних форм у значенні неможливості досягнення результату трапляється у мові значно частіше, оскільки носії мови неохоче використовують форму заперечення із модальними дієсловами, що, можливо, пояснюється необхідністю приведення висловлювання до кількісно-ритмічної норми [Тань 2002, 321]. Потенційна форма характеризується:

- модусом полеміки;

- обов'язковістю пресупозиції з боку слухача;

- безвідносністю до ознаки контрольованості дії і до поточного стану мовця;

- обмеженістю сполучуваності із багатьма РК, хоча деякі з них вживаються тільки у потенційній формі;

- вказівкою на граничність предиката [Тань 2002, 334].

Розглянемо такі приклади:

19) 原来有些事情不是你想逃避就能逃得了。Yuánlái yǒuxiē shìqíng bùshì nǐ xiăng táobì jiù néng táodeliăo. - Виявляється, що $є$ речі, яких не можна уникнути, навіть якби захотів. У цьому прикладі потенційна форма РК “逃得了 táodeliăo" - «могти втекти/уникнути» вказує на можливість досягнення межі дією, при цьому уся подія трактується як ірреальна, бо висувається сумнів стосовно успішності дії [Тань 2002, 315]. Для підсилення значення можливості використовується модальне дієслово “能 néng” разом із потенційною формою; 
20) 我心里暗暗自问, 一时却找不到答案。Wǒ xīnlǐ àn'àn zìwèn, yīshí què zhăo bù dào dá'àn. - Я потай питав себе, проте одразу не зміг знайти відповіді;

21）而且, 身体免疫力差, 极易生病, 一般活不过20岁。Érqiě, shēntǐ miănyì lì chà, jí yì shēngbìng, yībān huó buguò 20 suì. - Також, якщо імунітет слабкий, легко підхоплюєш хворобу, то зазвичай не можна прожити й 20 років.

У прикладах 20 та 21 потенційні форми РК вказують на неможливість досягнення дією межі. При цьому у реченні 21 мовець не впевнений у можливості об'єкта виконати дію.

Висновки та перспективи подальших досліджень. Семантика аспектуальної категорії результативності включає такі компоненти, як динамічність, граничність, цілісність, моментальність, фактивність, оцінна модальність та модальність можливості.

Ці компоненти реалізуються за допомогою різних синтаксичних елементів та компонентів результативної конструкції. До того ж фактивність та модальність $€$ факультативними ознаками, а інші характеристики $є$ постійними.

Перспективи подальших досліджень полягають у вивченні ролі інших засобів вираження результативної семантики, а також більш глибокому дослідженні структури та функцій результативних конструкцій.

\section{ЛIТЕРАТУРА}

Антонян К.В. Морфология результативных конструкций в китайском языке. Москва : Муравей, 2003. 270 с.

Бондарко А.В. Понятийные категории и языковые семантические функции. Универсалии и типологические исследования. Мещаниновские чтения. Москва : Наука, 1974. С. 54-79.

Бондарко А.В. Теория значения в системе функциональной грамматики: на материале русского языка. Москва : Языки славянской культуры, 2002. 736 с.

Любимова Ю.С. Потенциальное наклонение глагола как доминанта субполя возможности в современном китайском языке. Austrian Journal of Humanities and Social Sciences. 2016. № 1-2. C. 35-37.

Маслов Ю.С. Избранные труды: Аспектология. Общее языкознание. Москва : Языки славянской культуры, 2004. 840 с.

Плунгян В.А. Введение в грамматическую семантику: грамматические значения и грамматические системы языков мира. Москва : Издательство Российского государственного гуманитарного университета, 2011. 627 с.

Тань А. Проблемы скрытой грамматики: синтаксис, семантика и прагматика изолирующего строя (на примере китайского языка). Москва : Языки славянской культуры, 2002. 896 с.

Теория функциональной грамматики: введение. Аспектуальность. Временная локализованность. Таксис / А.В. Бондарко и др. ; под ред. А.В. Бондарко. Ленинград : Наука, 1987. 348 с.

Яхонтов С.Е. Категория глагола в китайском языке. Ленинград : Издательство Ленинградского университета, 1957. 183 с.

Bybee J., Perkins R., Pagliuca W. The evolution of grammar: Tense, aspect, and modality in the languages of the world. Chicago/London : University of Chicago Press, 1994. $414 \mathrm{p}$. 
Comrie B. Aspect: An introduction to the study of verbal aspect and related problems. Cambridge : Cambridge University Press, 1976. 142 p.

Loar J.K. Chinese Syntactic Grammar. Functional and Conceptual Principles. New-York : Peter Lang Publishing, 2011. 494 p.

Smith C.S. The parameter of Aspect. Dordrecht : Springer Science+Business Media, 1997. 353 p.

Xiao R, McEnery T. Aspect in Mandarin Chinese: A corpus-based study. Amsterdam/Philadelphia : John Benjamin's Publishing Company, 2004. 303 p.

王艳. 东亚语言结果式的类型学研究. 上海外国语大学博士学位论文/王艳, 2017. 322 页.

\section{REFERENCES}

Antonyan K.V. (2003), Morfologiya rezul'tativnykh konstruktsiy v kitayskom yazyke, Muravey, Moskva. (In Russian).

Bondarko A.V. (1974), "Ponyatiynyye kategorii i yazykovyye semanticheskiye funktsii”, Universalii i tipologicheskiye issledovaniya. Meshchaninovskiye chteniya, Nauka, Moskva, pp. 54-79. (In Russian).

Bondarko A.V.(2002), Teoriya znacheniya v sisteme funktsional'noy grammatiki: Na materiale russkogo yazyka, Yazyki slavyanskoy kul'tury, Moskva. (In Russian).

Bybee J., Perkins R. and Pagliuca W. (1994), The evolution of grammar: Tense, aspect, and modality in the languages of the world, University of Chicago Press., Chicago/London.

Comrie B. (1976), An introduction to the study of verbal aspect and related problems, Cambridge University Press, Cambridge.

Loar J.K. (2011), Chinese Syntactic Grammar. Functional and Conceptual Principles, Peter Lang Publishing, New York, NY.

Lyubimova Yu.S. (2016), "Potentsial'noye nakloneniye glagola kak dominanta subpolya vozmozhnosti v sovremennom kitayskom yazyke", Austrian Journal of Humanities and Social Sciences, No. 1-2, pp. 35-37. (In Russian).

Maslov Yu.S. (2004), Izbrannyye trudy: Aspektologiya. Obshcheye yazykoznaniye, Yazyki slavyanskoy kul'tury, Moskva. (In Russian).

Plungyan V.A. (2011), Vvedeniye $\mathrm{v}$ grammaticheskuyu semantiku: grammaticheskiye znacheniya i grammaticheskiye sistemy yazykov mira, Izdatel'stvo Rossiyskogo gosudarstvennogo gumanitarnogo universiteta, Moskva. (In Russian).

Smith C.S. (1997), The parameter of Aspect, Springer Science+Business Media, Dordrecht.

Tan'A. (2002), Problemy skrytoy grammatiki: Sintaksis, semantika i pragmatika izoliruyushchego stroya (na primere kitayskogo yazyka), Yazyki slavyanskoy kul'tury, Moskva. (In Russian).

Teoriya funktsional'noy grammatiki: Vvedeniye. Aspektual'nost'. Vremennaya lokalizovannost'. Taksis (1987), Bondarko A.V. (Ed.), Nauka, Leningrad. (In Russian).

Wang Yan (2017), Dong ya yuyan jieguo shi de leixing xue yanjiu. (In Chinese).

Xiao R, McEnery T. (2004), Aspect in Mandarin Chinese: A corpus-based study, John Benjamin's Publishing Company, Amsterdam/Philadelphia. 
Yakhontov S.E. (1957), Kategoriya glagola v kitayskom yazyke, Izdatel'stvo Leningradskogo universiteta, Leningrad. (In Russian).

Bybee J., Perkins R., Pagliuca W. The evolution of grammar: Tense, aspect, and modality in the languages of the world. Chicago/London : University of Chicago Press, 1994. $414 \mathrm{p}$.

Comrie B. Aspect: An introduction to the study of verbal aspect and related problems. Cambridge : Cambridge University Press, 1976. 142 p.

Loar J.K. Chinese Syntactic Grammar. Functional and Conceptual Principles. New-York : Peter Lang Publishing, 2011. 494 p.

Smith C.S. The parameter of Aspect. Dordrecht : Springer Science+Business Media, 1997. $353 \mathrm{p}$.

Xiao R, McEnery T. Aspect in Mandarin Chinese: A corpus-based study. Amsterdam/Philadelphia : John Benjamin's Publishing Company, 2004. 303 p.

王艳. 东亚语言结果式的类型学研究. 上海外国语大学博士学位论文/王艳, 2017. 322 页.

Стаття надійшла до редакиії 11.11.2021. 